\title{
The Role of Calmodulin and Related Proteins in Plant Cell Function: An Ever-Thickening Plot
}

\author{
D. R. Bergey $\cdot$ R. Kandel $\cdot$ B. K. Tyree $\cdot$ \\ M. Dutt · S. A. Dhekney
}

Received: 9 February 2014/Revised: 12 September 2014/Accepted: 28 October 2014/Published online: 18 November 2014

(c) Springer International Publishing AG 2014

\begin{abstract}
Stimuli-induced fluctuations in intracellular free calcium $\left(\mathrm{Ca}^{2+}\right)$ serve as secondary messenger signals that regulate diverse biochemical processes in eukaryotic cells, such as developmental transitions and responses to biotic and abiotic stresses. Stimuli-specific $\mathrm{Ca}^{2+}$ signals are manifested as spatially and temporally defined differential $\mathrm{Ca}^{2+}$ signatures that are sensed, decoded, and transduced to elicit distal responses via an array of $\mathrm{Ca}^{2+}$ binding proteins (CBPs) that function as intracellular $\mathrm{Ca}^{2+}$ sensors. Calmodulin (CaM), the most important eukaryotic CBP, senses and responds to fluctuations in intracellular $\mathrm{Ca}^{2+}$ levels by binding to this ubiquitous second messenger, and transducing given $\mathrm{Ca}^{2+}$ signatures that differentially activate distal effector (target) proteins regulating a broad range of biochemical responses. $\mathrm{Ca}^{2+} / \mathrm{CaM}$ targets include an increasing number of proteins whose functions continue to be elucidated. Hundreds of reports have highlighted the importance of $\mathrm{CaM}$, and other CBPs, in the transduction of $\mathrm{Ca}^{2+}$-mediated signals involved in transcriptional regulation, protein
\end{abstract}

Endorsed by Sadanand Dhekney.

D. R. Bergey · R. Kandel · S. A. Dhekney $(\bowtie)$

Sheridan Research and Extension Center, University of

Wyoming, 663 Wyarno Road, Sheridan, WY 82801, USA

e-mail: sdhekney@uwyo.edu

B. K. Tyree

Sheridan College, 3401 Coffeen Avenue, Sheridan, WY 82801, USA

M. Dutt

Citrus Research and Education Center, University of Florida, 700 Experiment Station Road, Lake Alfred, FL 33850, USA phosphorylation/dephosphorylation, and metabolic shifts. Other $\mathrm{Ca}^{2+}$-binding proteins are known to play significant functional roles in plant cells as well. This review is primarily focused on the role of CaM in some key plant processes, and discusses recent advances in understanding the pivotal role of $\mathrm{CaM}$ in an ever-increasing number of plant cell functions and biochemical responses. We also discuss recent work highlighting the emerging importance of $\mathrm{CaM}$ in nuclear and organellar signaling.

Keywords Calcium · Calmodulin · Intracellular signaling $\cdot$ Plant defense $\cdot$ Secondary messenger

\section{Introduction}

The free calcium ion $\left(\mathrm{Ca}^{2+}\right)$ emerged very early during evolution as a critically important soluble secondary messenger, and became a fundamental intracellular signaling component in an array of developmental and physiological processes and responses to biotic and abiotic stresses [139]. $\mathrm{Ca}^{2+}$ signals originate from several sources in eukaryotic cells, including the extracellular space and release from intracellular stores. Eukaryotic cells have evolved several membrane-bound channel and pump systems that ensure $\mathrm{Ca}^{2+}$ levels in the cytosol are maintained at significantly lower levels (up to 10,000-fold lower) than the extracellular environment and within various organelles, such as the endoplasmic reticulum (ER). These dramatic concentration gradients provide potent force potentials that can be exploited for modulating various cellular processes in response to dynamic changes in $\mathrm{Ca}^{2+}$ concentrations across membranes. Major $\mathrm{Ca}^{2+}$ storage compartments in plants include the vacuole, ER, and the apoplast. More recently other organelles such as the chloroplast, mitochondria, and 
nucleus have also been implicated for their role in $\mathrm{Ca}^{2+}$ signaling $[32,90,146,162]$. Most current research on $\mathrm{Ca}^{2+}$ signaling in plants is focused on characterizing cytosolic $\mathrm{Ca}^{2+}$ flux parameters and the molecules that sense, decode, and transduce these intracellular $\mathrm{Ca}^{2+}$ signals [56, 80, 90, 96, 140].

When intracellular $\mathrm{Ca}^{2+}$ concentrations increase above threshold levels, potentially cytotoxic calcium salts such as $\mathrm{Ca}_{3}\left(\mathrm{PO}_{4}\right)_{2}$ can precipitate and trigger apoptotic cell death and disrupt cellular processes [9, 99, 101, 183]. Therefore, active removal of $\mathrm{Ca}^{2+}$ from the cytosol appears to have been an evolutionary prerequisite for cells to develop life-sustaining processes. This would be beneficial since removal of $\mathrm{Ca}^{2+}$ from the cell would minimize, or prevent, random chelation of negatively charged molecules. Notably, the ability to minimize and regulate intracellular $\mathrm{Ca}^{2+}$ levels would also allow a minimal concentration of soluble phosphate ion to persist in the cytosol and establish conditions that would favor subsequent selection and development of phosphate-based metabolic processes. In plant cells, cytosolic levels of $\mathrm{Ca}^{2+}$ are actively maintained in the range of ca. 100-200 nM, whereas the cell wall space, vacuole, and ER compartments typically have levels between 1 and $10 \mathrm{mM}[30,43,56,93$, 120, 171].

A multitude of stimuli including hormones, light, gravity, biotic and abiotic stresses, and defense responses to pathogens or trauma can activate rapid, transient spikes in intracellular $\mathrm{Ca}^{2+}$ levels. A critical determinant of a cell's response specificity to a given stimulus is the $\mathrm{Ca}^{2+}$ influx signature characterized by its duration, amplitude, frequency, and location. The other critical determinant is the presence, or absence, of specific $\mathrm{Ca}^{2+}$-binding (sensor) proteins that are differentially activated when bound to $\mathrm{Ca}^{2+}$. These activated $\mathrm{Ca}^{2+}$-binding proteins decipher and transduce given $\mathrm{Ca}^{2+}$ signatures (i.e., differential stimuli) to specific physiological responses by interacting with, and differentially regulating, various downstream effector molecules, such as kinases, transcription factors, and lipases. However, it remains unclear how the cell selectively tailors distal intracellular responses to subtle qualitative changes in proximal $\mathrm{Ca}^{2+}$ influx signatures such as influx spike frequency, amplitude, and duration. In its role as a classic second messenger molecule, $\mathrm{Ca}^{2+}$ relays signals from specific cell surface receptors (primary messengers) to various intracellular target molecules that, in turn, directly mediate changes in diverse cellular activities, developmental processes, and stress or defense-related responses. Major challenges remain in elucidating how the cell deciphers exquisitely subtle variations in stimuli-specific $\mathrm{Ca}^{2+}$ signatures and precisely integrates corresponding distal cellular responses.

\section{Calcium-Binding Proteins}

Eukaryotes have evolved a large array of $\mathrm{Ca}^{2+}$-binding proteins (CBPs) that effectively buffer intracellular $\mathrm{Ca}^{2+}$ levels to maintain internal $\mathrm{Ca}^{2+}$ homeostasis, and serve as sensors that govern distal $\mathrm{Ca}^{2+}$-dependent cellular responses. Hundreds of proteins involved in calcium signaling networks have been identified in plants, and the number of downstream targets regulated by these calcium sensor proteins continues to increase. Many of these CBPs play crucial cellular roles by differentially modulating a range of cellular activities in response to specific $\mathrm{Ca}^{2+}$ influx signatures. CBPs have been under increasing scrutiny in recent years as they have been found to play roles in an expanding range of plant cell functions and processes.

Interaction of a given $\mathrm{CBP}$ with $\mathrm{Ca}^{2+}$ results in the formation of biologically active $\mathrm{Ca}^{2+} / \mathrm{CBP}$ complex. These active complexes, in turn, initiate biological responses by either altering the inherent activity of the specific CBP directly, or by interacting with other effector molecules such as enzymes, transcription factors, cytoskeletal components, or even DNA to regulate cellular activities or initiate signaling cascades, which amplify the primary signal. Collectively, CBPs form a cellular network of integrated stimulus-response feedback loops that regulate the relative response levels, and resulting distal cellular effects, of the calcium signal. Over the past few years, an increasing number of CBPs has been identified and characterized, and it is clear the extent of their functional diversity will continue to expand as progress in understanding the regulatory parameters and complex interplay of $\mathrm{Ca}^{2+}$-mediated plant signaling pathways advances.

CBPs can be divided into a handful of major sub-groups, which include calmodulin (CaM), CaM-like proteins (CML), calcineurin B-like proteins (CBLs) and their interacting kinases (CIPKs) [11, 12, 111, 155], calciumdependent protein kinases (CDPKs) [7, 26, 95, 188], and various protein kinase signaling networks in plant innate immunity [168]. In plant genomes, these sub-groups of $\mathrm{Ca}^{2+}$ sensors exist as multi-gene families that form sophisticated signaling networks that integrate the information processing controlling diverse cellular processes. $\mathrm{CaM}$ is highly conserved, found in all eukaryotes, and is the most important of all known CBPs. However, in contrast to CaM, the CMLs, CBLs, and CDPKs are found primarily only in plants. The focus of this review is CaM, and thus CMLs and other $\mathrm{Ca}^{2+}$-binding proteins will not be discussed in great detail here. More in-depth discussion on calcium signaling and related CBPs can be found in the following reviews [12, 56, 80, 137], and an entire issue of Plant Physiology dedicated to calcium signaling (October 2013, vol. 163). 
Over the past several years an increasing number of plant species have been subjected to whole genome sequencing, analysis, and profiling. Sequencing data to date has revealed the existence of multiple genes that encode identical or highly homologous CaM isoforms (97-99 \% identity), and further indicated that a diverse assortment of CMLs is a common feature of higher plant, but not animal, genomes [47, 199]. All eukaryotic CBPs, including $\mathrm{CaM}$, possess one or more discrete amino acid domains called $\mathrm{E}-\mathrm{F}$ hands that can bind $\mathrm{Ca}^{2+}$. In a genome-wide analysis of Arabidopsis thaliana, Day et al. [47] identified 250 genes encoding proteins that contained at least one predicted EF-hand motif. Seven of these genes encoded four CaM isoforms sharing 97-99\% amino acid identity with each other, and a high level of sequence identity with $\mathrm{CaM}$ isoforms found in vertebrates and insects. Based on these two criteria these four isoforms are considered to be typical $\mathrm{CaM}$ proteins, as compared to CMLs or other CBPs.

Eukaryotic cells have developed a multitude of ways to exploit intracellular $\mathrm{Ca}^{2+}$ gradients to regulate cellular processes. $\mathrm{Ca}^{2+}$ acts as a diffusible second messenger by relaying information from initial stimuli to activate cellular responses, and its critical role in eukaryotic intracellular signaling is well established. CaM has evolved to be the primary transducer of $\mathrm{Ca}^{2+}$ signals in eukaryotic cells. Structurally, CaM consists of a single polypeptide, typically 148 amino acids long, that has no known inherent biological activity until binding $\mathrm{Ca}^{2+}$. Each $\mathrm{CaM}$ protein contains two globular $\mathrm{Ca}^{2+}$-binding domains, and each of these domains has two EF-hand motifs capable of binding one $\mathrm{Ca}^{2+}$ ion each. Therefore, each CaM protein can bind up to four $\mathrm{Ca}^{2+}$ ions.

The EF hand is a helix-loop-helix structure consisting of about 40 amino acids that is one of the most common structural motifs found in plant and animal genomes-an observation that is consistent with $\mathrm{Ca}^{2+}$ being a versatile and ubiquitous messenger for dynamic regulation of cellular signaling pathways. EF-hand domains are often found in single or multiple pairs, giving rise to various structural variations in proteins that contain EF-hand motifs. These structural variations confer functional diversity to these proteins that provides the cell with the capacity to integrate and fine-tune target molecule binding, and subsequent distal cellular responses, to a broad continuum of differential $\mathrm{Ca}^{2+}$ influx signatures. In animal genomes, for example, over 1,000 different genes have been identified from their unique EF-hand sequence motifs [33, 81].

In both plants and animals, there is a notable lack of understanding on how the integral EF-hand domains in $\mathrm{CaM}$ and other CBPs impart differential specificity to these
$\mathrm{Ca}^{2+}$ sensors, and what subtle structural shifts enable these proteins to distinguish among the numerous known target proteins within the cells they regulate. The presence of EFhand motifs in all classes of CBPs is consistent with $\mathrm{Ca}^{2+}$ being a global intracellular regulator.

$\mathrm{CaM}$ itself is a monomeric peptide containing two symmetrical, globular $\mathrm{Ca}^{2+}$-binding domains. Each domain contains two canonical EF-hand motifs that are separated by a flexible alpha helix linker sequence. The flexibility of this linker sequence between the EF-hand motifs is a defining structural feature for CaM function in that it allows the $\mathrm{Ca}^{2+}$-activated $\mathrm{CaM}$ peptide to wrap around and form a stable complex with the target molecule being regulated. Binding of calcium to the two helix-loop-helix $\mathrm{Ca}^{2+}$-binding motifs in each of the globular domains induces conformational changes that expose a methionine-rich hydrophobic patch on the surface of each domain of the protein, which promotes binding to specific peptide sequences present in specifically bound target proteins [191]. Using a structural systems approach Velayev et al. [179] concluded that specificity and selectivity of $\mathrm{CaM}$ target regulation likely depends upon two key factors: (1) variations in targetspecific $\mathrm{Ca}^{2+}$ dissociation and cooperatively effected association constants, and (2) variations in the threshold number of $\mathrm{Ca}^{2+}$ ions required to bind $\mathrm{CaM}$ for effective target activation. Binding of $\mathrm{Ca}^{2+}$ to EF-hand domains induces a conformational change in $\mathrm{CaM}$ that is transmitted to its target proteins to, typically, catalyze enzymatic reactions.

CMLs are characterized by possessing two to six predicted EF-hand motifs, lacking any other known functional domain, and having at least $15 \%$ amino acid homology with CaMs. The CaM/CML gene family in Arabidopsis consists of seven CaM and fifty CML genes [121, 137], while the rice genome comprises of five $\mathrm{CaM}$ and thirtytwo CML genes [24]. Although overlapping and redundant functional roles are frequently observed for some $\mathrm{CaM}$ isoforms, it is known that different $\mathrm{CaM}$ gene variants can exhibit distinct, yet often subtle, patterns of temporal or spatial regulation and differentially affect various biological functions.

Comparisons between CaM and CML genes, and amino acid sequences, indicated that CMLs can be broadly classified into two major groups. One group of CMLs displays significant sequence identity $(>50 \%)$ with $\mathrm{CaM}$ and contains an intron at the same position found in CaM genes, indicating close evolutionary relationship with CaM. In contrast, the second CML group displays low homology $(<50 \%)$ with $\mathrm{CaM}$, and exhibits high structural divergence suggesting novel functions for the various isoforms [80, 121, 137, 140]. 


\section{Calcium Signal Transduction by CaM}

The transduction of a $\mathrm{Ca}^{2+}$ signal can be viewed as a twostep process involving an initial activation of $\mathrm{CaM}$ (or any CBP) by the ionic signal, followed by binding to, and modulation of, a specific target protein. Since $\mathrm{Ca}^{2+}$ signatures result from the coordinated action between $\mathrm{Ca}^{2+}$ influx and efflux pathways, how $\mathrm{Ca}^{2+}$-permeable channels and transporters are regulated during calcium signaling processes, including plant-pathogen interactions, must be considered. CaM found in plants and animals can bind up to four $\mathrm{Ca}^{2+}$ ions. In animals, $\mathrm{CaM}$ also undergoes posttranslational modifications such as phosphorylation, acetylation, methylation, and proteolytic cleavage, each of which can potentially modulate its activity. Although posttranslational modification of $\mathrm{CaM}$ has yet to be carefully investigated in animals, it is likely that similar kinds of modifications occur to plant CaMs as well to endow cells with another strategy for fine-tuning the regulatory effects of $\mathrm{CaM}$ on cellular processes. For example, recent work by Banerjee et al. [11] examining CaM $N$-methyltransferase (CaM KMT) activity confirmed that the methylation status of CaM plays a role in CaM-mediated signaling. In Arabidopsis plants overexpressing, partially expressing, or knocked out with regard to CaM KMT, the authors found differential, discrete spatial- and tissue-specific patterns of CaM KMT expression in these transgenic plant lines. Moreover, microarray analysis revealed numerous putative target proteins having specificity for methylated CaM. Differential methylation of CaM thus adds another strategy for expanding the target protein repertoire mediated by $\mathrm{Ca}^{2+} / \mathrm{CaM}$ signaling, and fine-tuning their differential activity.

\section{CaM Target Molecules in Plants}

$\mathrm{CaM}$ interacts with a wide range of downstream target molecules, mainly proteins that mediate diverse cell processes. The list of CaM-binding proteins continues to expand and includes transcription factors, kinases and phosphatases, ion channels, membrane transporters, and metabolic regulators. A comprehensive list of known plant CaM-binding proteins can be found in Poovaiah et al. [140].

Several important target proteins known to bind $\mathrm{CaM}$ and mediate key plant cell processes will be discussed.

\section{Mitogen-Activated Protein Kinases}

Mitogen-activated protein kinases (MAPKs) are evolutionarily conserved proteins that function as key signal transducers of external stimuli in plants, animals, and fungi. MAPK cascades are known to regulate processes involved in plant growth and development, and cellular responses to biotic and abiotic stresses $[27,46,63,65,145$, $147,154,165]$. The lesser understood MAPK phosphatases (MKPs) also play key roles in regulating biotic and abiotic processes through their ability to deactivate MAPK signaling cascades by altering activation levels and kinetics of MAP kinases [75, 104, 131]. After screening an Arabidopsis cDNA library, Lee et al. [104] identified an MKP (AtMKP1) and subsequently demonstrated that it binds $\mathrm{CaM}$ in a $\mathrm{Ca}^{2+}$-dependent manner. Moreover, $\mathrm{CaM}$ binding was confirmed to enhance the phosphatase activity of AtMKP1 in a $\mathrm{Ca}^{2+}$-dependent manner. Recent work shows specific interaction among individual MAPKs and cognate MKPs in plant responses to UV light stress [75], and regulatory integration of these antagonistic activities with other defense signals (JA, SA, and ET) in plant immune responses [131]. Unraveling the discrete regulatory circuits governed by given MAPK-MKP pairs will be an ongoing challenge.

$\mathrm{Ca}^{2+}$ is known to regulate and activate MAPKs and cyclin dependent protein kinases, or CDPKs $[6,26,69$, $107,138,168,188]$. A growing body of evidence implicates CaM in the activation of specific MAPK variants. For example, Arabidopsis MPK8 is activated through mechanical wounding and requires direct binding of CaMs in a $\mathrm{Ca}^{2+}$-dependent manner [166], and other reports have described CaM-mediated activation of specific MAPKs [104, 107]. Moreover, CaM signaling through the MAPK pathway and elevations in cytosolic $\mathrm{Ca}^{2+}$ are hallmarks of general plant stress responses [104, 136, 147, 160, 165, $166,188,189]$. The functional coordination of $\mathrm{Ca}^{2+}$ and MAPK interaction may occur through the formation of unique CaM-MAPK phosphatase multi-protein complexes [83, 144, 166].

Deciphering the complex cross-talk among MAPKs and various other signaling messengers such as nitric oxide (NO), reaction oxygen species (ROS), jasmonic acid (JA), salicylic acid (SA), and ethylene is an intensely active area of research, but will be discussed here in limited context only where CaM involvement has been clearly established. More exhaustive coverage of these areas can be found in recent reviews, including Boudsocq and Sheen [26], Liese and Romeis [108], Meng and Zhang [122], Sanchez-Barrena et al. [155], Danquah et al. [46], Romeis and Herde [151], and Smékalová et al. [161].

\section{WRKY Transcription Factors}

WRKY transcription factors are a large superfamily of transcriptional regulators unique to plants that are involved in signal transduction networks that govern an increasing number of physiological processes including responses to 
biotic and abiotic stresses [34, 153, 172], systemic acquired resistance (SAR), and the hypersensitive response (HR) $[66,82]$. WRKY proteins can act as repressors, as well as activators, and often affect seemingly unrelated cellular processes. Most known WRKY transcription factors studied have been implicated in SA and/or JA signaling pathways, and several WRKY family members have been shown to interact with CaM [10, 11, 37, 134, 152]. Using a CaM probe to screen an Arabidopsis cDNA expression library, Park et al. [134] isolated positive clones encoding AtWRKY7, and demonstrated $\mathrm{Ca}^{2+}$-dependent $\mathrm{CaM}$ binding in gel mobility shift assays and competition assays using a $\mathrm{Ca}^{2+} / \mathrm{CaM}$-dependent enzyme. The AtWRKY7 protein contains a short amino acid stretch called the C-motif (VAVNSFKKVISLLGRSR) that functioned as the CaM-binding domain [134]. Chi et al. [37] noted that similar C-motif domains have been found in at least 10 other Arabidopsis WRKY proteins also bound by CaM.

A genome-wide analysis of $\mathrm{CaM}$ genes from three Solanaceous species (tomato, tobacco, and potato) by Zhao et al. [199] reported that upstream sequences from CaM genes carry a variety of potential regulatory motifs, including binding sites for transcription factors that are regulated by hormones such as abscisic acid (ABA), gibberellin (GA), auxin, JA, and ethylene. The sequence patterns of these upstream elements differed significantly among the tomato $\mathrm{CaM}$ genes suggesting differential regulation potential. For example, one tomato $\mathrm{CaM}$ gene promoter contained several sequence elements that could potentially respond to all five noted hormones, while the other tomato $\mathrm{CaM}$ family members completely lacked elements responsive to one or more of these hormones. Notably, all tomato $\mathrm{CaM}$ genes contained upstream elements having multiple $\mathrm{W}$-box elements, which are the cisacting regions specifically recognized by WRKY transcription factors. These results strongly suggest that all tomato $\mathrm{CaM}$ genes are regulated, at least to some degree, by WRKY transcription factors.

\section{IQD Proteins}

IQD proteins (also referred to as IQ67-domain proteins) are a large group of plant-specific CaM/CML-target molecules that share a unique common domain comprised of multiple CaM retention motifs in tandem orientation. Genetic studies in Arabidopsis and tomato have revealed roles for IQD proteins in plant defense responses and plant development, but specific functions for most IQD proteins have not been determined. A recent genome-wide comparative screen of Arabidopsis and rice revealed the presence of 33 and 29 IQD proteins, respectively [3]. All 33 predicted Arabidopsis IQD proteins share a unique conserved domain of 67 amino acids that is characterized by a specific arrangement of multiple $\mathrm{CaM}$ recruitment domains, in tandem orientation, referred to as IQ motifs. Therefore, all IQD family members are potential CaM targets.

A specific IQD isoform, IQD1 (also known as IQ67 domain 1), contains several CaM-binding motifs as well as a putative nuclear localization signal. Glucosinolates are a class of secondary metabolites, primarily characterized in Brassicaceae species, that have important functions in human nutrition and plant defense against microbes and herbivory [1, 15, 84, 109, 186]. Levy et al. [106] screened Arabidopsis thaliana T-DNA activation-tagged lines and identified a high-glucosinolate mutant caused by overexpression of IQD1. Overexpression had increased levels of glucosinolates, as well as reduced herbivory, whereas lossof-function iqd1 mutants had reduced glucosinolate levels. The authors proposed that IQD1 integrates intracellular $\mathrm{Ca}^{2+}$ signals to fine-tune glucosinolate accumulation in response to biotic challenges. Burstenbinder et al. [29] showed that IQD1 binds to multiple Arabidopsis CaM and CML proteins in yeast two-hybrid interaction assays, and in vitro. Green florescent protein (GFP)-tagged IQD1 proteins were found to localize to the microtubules, nucleus, and nucleolus in transiently and stably transformed plant tissues. Since IQD1 harbors several nuclear localization signals and localizes to the nucleus, it is likely that IQD1 regulates gene expression by interacting with DNA.

Burstenbinder et al. [29] and Abel et al. [4] suggested that IQD1 and related proteins provide $\mathrm{Ca}^{2+} / \mathrm{CaM}$-regulated scaffolds for facilitating cellular transport of specific cargo along microtubular tracks via kinesin motor proteins. IQD1 has also been shown to interact in vitro with single-stranded nucleic acids, suggesting it and related IQD family members, facilitates cellular RNA localization as a means of finetuning gene expression and protein sorting [4].

\section{Plant Cyclic Nucleotide-Gated Ion Channels}

Plant cyclic nucleotide-gated ion channels (CNGCs) function as non-selective cation channels and play key roles in development, ion homeostasis, thermotolerance, and defense responses by providing a pathway for $\mathrm{Ca}^{2+}$ and $\mathrm{K}^{+}$ movement across the plasma membrane $[2,40,59,88,112$, 113, 123, 180, 197]. CNGCs are found in the plasma membranes of plant, animal, and (recently) prokaryotic cells. These ancient cation channels are activated by cyclic nucleotides that bind at specific channel sites that partially overlap the CaM-binding sites they also possess [197]. Binding of CaM results in the inactivation of the CNGCs by interfering with the binding of cyclic nucleotides via competitive inhibition. The negative action of CaM on CNGC activity therefore provides an intriguing negative feedback system that allows $\mathrm{Ca}^{2+}$ itself to restrict its own influx into plant cells, or across intracellular membranes [112, 180]. 
During plant immune responses, elevations of CNGCdependent $\mathrm{Ca}^{2+}$ activate a signaling cascade that results in the accumulation of defense-related molecules, such as $\mathrm{H}_{2} \mathrm{O}_{2}$ and $\mathrm{NO}$, and the induction of defense gene expression [180]. Fischer et al. [61] showed that a specific CNGC (CNCG20) from Arabidopsis thaliana binds CaM in a $\mathrm{Ca}^{2+}$-dependent manner and also interacts with all known AtCaM isoforms, but not with the CaM-like proteins CML8 and CML9. GFP-localization studies by the same authors further showed that this interaction occurred at the plasma membrane.

Although IQ domains are known to be conserved among plant CNGCs [197], the CaM-binding site within CNGC20 was identified as an isoleucine glutamine (IQ) domain, which had not been reported previously for any plant CNGCs. It was also revealed that the binding sites for cyclic nucleotides and $\mathrm{CaM}$ within $\mathrm{CNGC} 20$ are sequentially arranged, rather than overlapping [61]. This particular structural difference is also unique for CNGC20, compared to corresponding binding sites found in other known plant CNGCs. The presence of alternative binding domains in CNGC20 expands the regulatory potential of the cell for controlling $\mathrm{Ca}^{2+}$-dependent channel activity, and clearly indicates that ligand-mediated regulation of plant CNGC activity is more complex than previously known for this functionally diverse gene family.

The role $\mathrm{Ca}^{2+}$-ATPases in cellular $\mathrm{Ca}^{2+}$ efflux mechanisms is well known, and in recent years it has become clear that these ion pumps also play key roles in sensing intracellular calcium fluctuations and transducing distal signals by activating specific target molecules to modulate corresponding metabolic pathways $[23,110] . \mathrm{Ca}^{2+}$-activated $\mathrm{CaM}$ plays vital roles in numerous stress tolerance responses, and the presence of a unique CaM-binding site in type IIB $\mathrm{Ca}^{2+}$-ATPases indicates their potential role in mediating biotic and abiotic stress tolerances [23, 64].

Autoinhibited $\mathrm{Ca}^{2+}$-ATPases (ACA) belong to a subgroup of CaM-regulated $\mathrm{Ca}^{2+}$-ATPases that contain an N-terminal CaM-binding site and an auto-inhibitory domain. CaM has been shown to stimulate the activity of these particular $\mathrm{Ca}^{2+}$ pumps by binding to this domain and preventing their auto-inhibition. Control of $\mathrm{Ca}^{2+}$ transport systems involving both CNGCs and ACAs can therefore be regulated by $\mathrm{CaM}[61,72]$.

\section{Calmodulin and Salicylic Acid}

Transient changes in intracellular calcium levels are crucial early signaling events in the activation of plant-pathogen interactions that initiate local defense and systemic acquired resistence, or SAR [103]. Salicylic acid (SA) is well known to be a key signal molecule in plant resistance, yet its precise functional role has yet to be clearly defined [66, 67, 73, 126, 127].

Doares et al. [55] showed that SA specifically inhibits JA- and systemin-mediated activations of proteinase inhibitor genes via the octadecanoid pathway, which is induced by wound trauma such as herbivory. Bergey et al. [20] purified and obtained partial amino acid sequence information to identify numerous proteins, including CaM, that were differentially regulated in transgenic tomato plants overexpressing the wound response peptide systemin, a potent activator of the octadecanoid (or JA) signaling pathway. This was the first report implicating CaM induction with the plant wound response and octadecanoid signaling. Since then an expanding body of work has established a central role for $\mathrm{CaM}$ in mediating interplay among numerous defense and stress-related responses [18, 21, 22, 36, 142, 173].

Although CaM and various CMLs have been clearly linked to SA-mediated responses to development, stress, and defense response, the nature of this interaction is just beginning to be unraveled [17, 42, 89, 173, 176, 178, 198].

\section{A $\mathrm{Ca}^{2+} / \mathrm{CaM}-$ Regulated Transcription Factor Family}

A family of $\mathrm{Ca}^{2+} / \mathrm{CaM}$-binding transcription factors generally referred to as signal responsive/CaM transcription activators (SR/CAMTAs) is known to play important roles in fruit ripening and response to myriad abiotic and biotic stresses [18, 21, 25, 60, 68, 78, 142, 194]. Using differential display, Zegzouti et al. [196] first identified a large class of cDNA clones from tomato that were differentially regulated by ethylene. This group of cDNAs were referred to as ethylene-regulated (ER) sequences, one of which was ER66. The following year Yang and Poovaiah [192] isolated and characterized a tobacco ER66 homolog after screening a tobacco anther cDNA library with 35S-labeled CaM. The authors referred to this homolog as an early ethylene-responsive up-regulated gene (NtER1), and this report was the first to link $\mathrm{Ca}^{2+} / \mathrm{CaM}$ signaling to ethylene activity. Reddy et al. [148] followed closely by identifying an ER66 homolog, and several related hypothetical sequences, in Arabidopsis. Yang and Poovaiah [193] subsequently characterized six NtER1-related proteins in Arabidopsis, and called these homologs Arabidopsis thaliana Signal Response genes (AtSRs). SR/CAMTA is the more general name for this family of CaM-binding transcription factors, and homologs of this family have since been found in all plant and animal species surveyed to date. All SR/CAMTA family members share a similar structural organization with a novel type of sequence-specific DNAbinding domain (designated CG-1) that directly binds DNA to activate transcription, or interact with other transcription factors to function as a co-activator. 
Du et al. [57] reported that plants with loss-of-function mutant alleles for atsr1 constitutively expressed genes associated with SAR, resulting in elevated SA levels and enhanced disease resistance. Moreover, the wild-type AtSR1 protein product was shown to be regulated by $\mathrm{Ca}^{2+}$ / $\mathrm{CaM}$, and to reduce $\mathrm{SA}$ levels via transcriptional repression of the gene encoding enhanced disease susceptibility 1 (EDS1), a protein previously shown to promote SA biosynthesis [185]. In work by Qui et al. [142] SR/CAMTA homogues in Arabidopsis (AtSRs or AtCAMTAs) responded differentially to wounding, and atsr1 mutants were more susceptible to herbivore attack than wild-type plants, and that complementation of the atsr1 mutant plants by overexpressing wild-type AtSR1 protein restored resistance to herbivore attack [142]. These authors further reported that the elevated levels of SA in atsr1 mutant plants suppressed both basal and induced biosynthesis of jasmonates, and concluded that $\mathrm{Ca}^{2+} / \mathrm{CaM}$ regulates the plant wound response by modulating, or coupling, JA-SA cross-talk through AtSR1.

AtSR1 also functions as a novel regulator of glucosinolate metabolism and subsequent herbivory tolerance in Arabidopsis [100]. Recently, Zhang et al. [198] provided some clarification on this system by identifying and characterizing an AtSR1 interaction protein 1 (called SR1IP1) that turns out to be an important component of ubiquitin ligase that is associated with AtSR 1 turnover. The authors showed that SR1IP1 is a loss-of-function mutant that was more susceptible to bacterial pathogens, and that overexpression of SR1IP1 conferred enhanced resistance, indicating that SR1IP1 acts as a positive regulator of plant defense. SR1IP1 contains the structural features of a substrate adaptor in E3 ubiquitin ligase, and was shown to function as a substrate adaptor that recruits AtSR1 for ubiquitination and subsequent degradation when plants are challenged with pathogens. Therefore, SR1IP1 positively regulates plant immunity by effectively removing the immune repressor AtSR1 [198]. A host of other transcription factors are known to interact with CaM [57, 87, $90,149,184,189$ ], thus ensuring a future of continuing discovery and deeper understanding of the complex circuitry involved in $\mathrm{Ca}^{2+} / \mathrm{CaM}$ signaling.

The complex, and typically antagonistic, interplay between JA and SA signaling in plant development and defense has been an area of intense investigative interest for several years, and will continue to provide challenges and rich intellectual rewards in coming years [52, 73, 178, 184]. As progress in this area continues to advance, differential regulation of CaM family isoforms will undoubtedly be confirmed as a common strategy for fine-tuning the crosstalk that coordinates the sophisticated interplay among these fundamental signaling pathways. Excellent recent reviews covering this area can be found in Reddy et al. [149], Weng et al. [184], Denancé et al. [51], Derksen et al. [52], Gimenez-Ibanez and Solano [73], and González et al. [74].

\section{CaM in Plant Defense and Stress Responses}

All animal and plant cells are continually threatened by invading microorganisms throughout their life spans. Although plants lack versatile and mobile sentinel cells such as macrophages and neutrophils found in animal innate immune systems, plant cells possess their own very effective innate immune systems that perceive and respond to invading pathogens and wound trauma. Like animals, plant innate immune response activation is triggered by the recognition of foreign (non-self) structural components called pathogen (or microbe) associated molecular patterns (PAMPs or MAMPs), which are essential, evolutionarily conserved components of pathogenic microbes. The recognition of PAMPs by pattern recognition receptor (PRRs) proteins localized in the host plasma membrane, and some intracellular membranes, leads to the activation of innate defense responses, referred to as PAMP-triggered immunity. Some excellent recent reports and reviews on this topic include [14, 35, 48, 62, 124, 127, 130, 158, 164, 169]. In addition, a recent book dedicated to innate pathogen recognition signals in plants is available.

All known plant PRRs identified to date are receptorlike kinases/proteins (RLK/Ps). Most plant viruses have RNA genomes that form inherent double-stranded RNA (dsRNA) structures that are recognized as PAMPs by plant cells, which subsequently activate defensive RNAi (RNA interference) responses as a fundamental antiviral defense strategy [53, 54].

In classic host-pathogen warfare style, selection pressure has lead to the result that most plant viruses now encode RNA silencing suppressor (RSS) proteins that can neutralize plant antiviral RNAi defense strategies. Many known RSSs bind dsRNAs, which can be functionally regarded as viral PAMPs. Tadamura et al. [164] recently identified a tobacco CaM-like protein, called rgs-CaM, as a putative PRR that is capable of binding to diverse viral RSSs by interacting with their dsRNA-binding domains and subsequently targeting the viral RSSs for autophagic degradation. Rapid induction of Rgs-CaM expression (within $1 \mathrm{~h}$ ) was observed at damaged sites following wounding of tobacco leaves. Plant virus entry into cells is typically associated with some kind of wound damage, therefore the rapid wound-induced expression of rgs-CaM suggests an early counter-attack strategy that would be initiated before an effective viral infection could be established. Known $\mathrm{CaM}$ and CML proteins transduce calcium signals by binding endogenous target molecules, whereas rgs-CaM appears unique in that it not only binds to 
exogenous targets but also functions as an antiviral PRR. Further evidence supporting rgs-CaM as a valid plant PRR was described by Nakahara et al. [129] who overexpressed rgs-CaM in tobacco and demonstrated increased resistance against viruses, and reduced resistance in plants in which rgs-CaM was repressed by RNAi.

Perception of, and interaction with, a pathogen can also result in the initiation of HR, which involves rapid programmed cell death (PCD) around the pathogen-infected site and prevents the spread of pathogen within the plant beyond the initial infection site. Production of primary signaling molecules such as NO and ROS are known to be key signaling events during the PCD process $[13,16,44$, 50, 76, 157, 181, 187]. Sphingolipids are essential components of all eukaryotic cell membranes that are known to play roles in plant defense and stress signaling [118, 125, $132,143]$. Synthesis of sphingolipids increases both cytosolic and nuclear levels of $\mathrm{Ca}^{2+}$ in plant cells [99, 135, 156], and recent work shows that sphingolipid metabolites are involved in the activation of calcium-dependent cell death $[20,99,170]$.

Harding et al. [79] overexpressed an endogenous dominant acting CaM mutant (VU-3) in tobacco cells, which resulted in elevated production of ROS. The authors also showed that VU-3 CaM differs from endogenous plant $\mathrm{CaM}$ in that it cannot be methylated post-translationally, and as a consequence directly hyperactivates CaM-dependent NAD kinase resulting in increased ROS production. This report was the first to provide evidence suggesting that CaM-activated NAD kinase potentiates ROS production in plants by altering $\mathrm{NAD}(\mathrm{H}) / \mathrm{NADP}(\mathrm{H})$ homeostasis.

Similar to animal cells, plant cells also utilize $\mathrm{Ca}^{2+}$ signaling as an essential early signaling event in response to pathogen perception. Transient elevations in cytosolic $\mathrm{Ca}^{2+}$ levels are a pivotal event in signaling pathways that trigger plant responses to a wide range of biotic stresses, including innate immune responses [36, 58, 137, 140, 149, 159], and it is well documented that $\mathrm{Ca}^{2+}, \mathrm{CaM}$, CMLs, and NO work together to mediate specific responses to pathogenic microorganisms and MAMPs $[41,78,86,114$, 180].

NO is a small redox-active gas that has become established as a central regulator of growth, development, and abiotic and biotic stress responses in plants. The primary molecular mechanism for initiating NO bioactivity is through S-nitrosylation, which involves the covalent attachment of NO to a protein cysteine thiol to form an S-nitrosothiol entity called SNO [195]. Abundant evidence supports $\mathrm{NO}$ as a key messenger involved in mediating $\mathrm{Ca}^{2+}$ signaling in plants, and in recent years it has become increasingly clear that $\mathrm{CaM}$ and $\mathrm{CML} \mathrm{Ca}{ }^{2+}$ sensor proteins play pivotal roles in NO production and plant defense signaling [86, 112, 113, 116, 175], as well as an ever- growing number of plant processes including developmental transitions, autophagy, and exposure to environmental stresses [75, 91, 102, 149, 175, 184, 189, 190, 194].

Arabidopsis lines expressing mutant forms of different CML genes exhibited elevated levels of $\mathrm{NO}$ and were responsible for FLOWERING LOCUS C transcript accumulation $[114,174]$. One of these CML gene products (CML24) was shown to interact directly with an autophagy related (ATG) gene to mediate progression of autophagy [36].

Arabidopsis showed that pathogen-induced $\mathrm{Ca}^{2+}$ results in $\mathrm{CaM}$ and/or CML activation of NOS, and that CaM antagonists prevent NO production and subsequent activation of the plant HR [114]. Overexpression of an animal CaM-dependent mammalian neuronal NOS (nNOS) in tobacco plants led to the spontaneous formation of lesions in leaves, the accumulation of high levels of SA and $\mathrm{H}_{2} \mathrm{O}_{2}$, and the up-regulation of an array of SA-, JA-, and ethylenerelated genes [42]. These transgenic tobacco plants also exhibited enhanced resistance to a broad range of pathogens including bacteria, fungi, and viruses. The authors proposed the likely existence of a sophisticated regulatory hierarchy involving NO in SA-, JA-, and/or ethylene (ET)dependent pathways that lead to disease resistance. Jeandroz et al. [86] showed that cytosolic $\mathrm{Ca}^{2+}$ fluxes initiated changes in NO production and provided the first evidence that $\mathrm{CaM}$ may be regulated at the post-translational level by NO through S-nitrosylation. Besides playing a critical role in plant immune signaling, several recent reports show that NO can mediate differential post-translational modifications (PTM) of various target proteins, and thus may have a much more expansive role in plant physiological processes $[8,70,182]$. Overall, these reports indicate that specific CML gene products transduce calcium signals that specifically regulate NO production to mediate plant cell processes.

Perception of pathogen signals by plants results in cyclic nucleotide production and the activation of CNGCs, which provide a conduit for $\mathrm{Ca}^{2+}$ movement across the plasma membrane and subsequent transient increases in cytosolic $\mathrm{Ca}^{2+}$ levels. CNGCs have been implicated in numerous signaling pathways $[113,115,123,180,197]$. Work by Ma [112] and Walker and Berkowitz [180] indicates that the recognition of pathogens results in cyclic nucleotide production and the activation of CNGCs, which leads to the production of pivotal signaling molecules such as NO. $\mathrm{CaM}$ and other CBPs are also involved in $\mathrm{Ca}^{2+}$ signaling processes that mediate the synthesis of NO during plantpathogen signaling [113, 141].

An increasing body of evidence points to the dynamic integration of $\mathrm{CaM} / \mathrm{CMLs}$, CNCGs, and NO, a fundamental signaling triad regulating a broad range of plant defense and stress responses [86, 112, 113, 123, 180]. 


\section{CaM in Biotic and Abiotic Stress Tolerances in Transgenic Plants}

$\mathrm{Ca}^{2+}$ influx is one of the earliest events to occur following biotic or abiotic stress in plant cells $[71,94,200]$, and $\mathrm{Ca}^{2+}$ influx has also been directly correlated with the activation of numerous endogenous defense responses including the induction of defense-related genes, and hypersensitive cell death $[28,77,92,105,167,184]$. Since the $\mathrm{Ca}^{2+}$ signal is necessary for the initiation of plant defense responses, transgenic plants that overexpress one of a number of the divergent $\mathrm{CaM}$ isoforms have been evaluated for their role in plant disease-resistance responses. Transgenic tobacco plants overexpressing the soybean CaM isoform 4 or soybean $\mathrm{CaM}$ isoform 5 gene were tolerant to Phytophthora parasitica var. nicotianae and Pseudomonas syringae pv. tabaci. In addition, these transgenic plants exhibited increased resistance to the tobacco mosaic virus (TMV) by developing TMV-induced HR lesions [82]. Overexpression of a synthetic gene-derived CaM (VU-3 CaM) in tobacco also resulted in enhanced levels of active oxygen species (AOS) in plants [79]. Salt stress-tolerant transgenic plants have been developed by overexpressing a calcineurin, a $\mathrm{Ca}^{2+} / \mathrm{CaM}$-dependent protein phosphatase [133].

In addition to an important role in biotic stress, CaMs have been observed to modulate abiotic stress in transgenic plants. Overexpression of the Nicotiana tabacum CaMbinding protein (NtCBP4) was observed to regulate plant tolerance to heavy metal and confer $\mathrm{Ni}^{+}$tolerance and $\mathrm{Pb}^{2+}$ hypersensitivity [5].

Trihelix-GT factors comprise a family of plant-specific transcription factors characterized by their binding specificity for GT-elements located in the promoters of many plant genes [128]. Xi et al. [189] identified a new member of the GT transcription factor family in Arabidopsis (AtGT2L) as a $\mathrm{Ca}^{2+} / \mathrm{CaM}$-binding protein, and demonstrated it was specifically targeted to the nucleus and possessed transcriptional activation and DNA-binding capability. The authors further showed that AtGT2L was induced by cold and salt $(\mathrm{NaCl})$ stress, as well as abscisic acid, and when overexpressed in transgenic plants enhanced the expression of known cold- and salt-inducible marker genes.

\section{CaM Function in Cellular Organelles}

$\mathrm{Ca}^{2+} / \mathrm{CaM}$-mediated regulation of a multitude of cytosolic processes is well established, and there are increasing numbers of reports demonstrating CaM and CML presence in various organelles such as chloroplasts, mitochondria, peroxisomes, and the nucleus [31, 39, 117, 163, 177]. In addition, processes such as protein import into chloroplasts and mitochondria have been shown to be governed by $\mathrm{CaM}$ regulation [85, 97, 119]. Jarrett et al. [85] reported that $\mathrm{CaM}$ entered the chloroplast and played a role in photosynthesis, and more recently chloroplast protein import has been shown to be influenced by calcium and $\mathrm{CaM}[38,39$, 163]. Using CaM-affinity chromatography and mass spectrometry, Dell'Aglio et al. [49] identified over 200 candidate CaM-binding proteins from Arabidopsis and spinach chloroplast sub-fractions. In vitro CaM-binding assays confirmed a subset of these proteins to be valid CaMbinding proteins. These results indicate there may be a much larger population of plastid targeted CaM-binding proteins than previously thought, and suggests $\mathrm{CaM}$ may be entering plastids to mediate various functions. These findings indicate that chloroplast protein import is integrated into the $\mathrm{Ca}^{2+}$-signaling circuit of the cell, and thus adds an additional, separate regulatory level for the chloroplast to define its protein complement and integrate its metabolic needs with those of the surrounding cell and tissue.

Peroxisomes are generally thought to be the primary source of NO in plants, mainly because NO and the enzyme responsible for the biosynthesis of NO, L-arginine-dependent NO synthase (NOS), are found in these oxidative organelles. Using calcium channel blockers and a $\mathrm{CaM}$ antagonist, Corpas et al. [45] showed that the import of the NOS protein into Arabidopsis peroxisomes is a $\mathrm{Ca}^{2+} / \mathrm{CaM}$ dependent process.

Signaling cross-talk among different organelles is an important aspect of cellular $\mathrm{Ca}^{2+}$ signaling that is gaining increasing interest with regard to dynamic intracellular reorganization in response to stimuli, the localization of $\mathrm{Ca}^{2+}$ effectors, $\mathrm{Ca}^{2+}$-dependent translocation, and posttranslational modifications of proteins. Kuhn et al. [97] showed that the import of nuclear-encoded mitochondrial proteins into the mitochondria of pea plants is influenced by calcium and $\mathrm{CaM}$, and that $\mathrm{Ca}^{2+}$-loaded $\mathrm{CaM}$ enters the nucleus, ostensibly to interact with transcription factors and regulate specific suites of genes [32, 90, 146].

In 1999 Rodríquez-Concepcíon et al. [150] showed that a previously unknown CaM variant (CaM53) from petunia is post-translationally isoprenylated at its C-terminal end. Using GFP fusion constructs the authors showed that inhibition of isoprenoid biosynthesis resulted in targeting of the CaM53 protein to protoplast nuclei, indicating that isoprenylation mediates the subcellular localization of this unusual CaM variant. In leaves exposed to light for several days, CaM53 was found to localize to the plasma membrane, whereas this $\mathrm{CaM}$ variant accumulated in the nucleus when leaves were maintained in the dark during the same period. However, nuclear translocation was blocked when leaves were exposed to dark on a medium supplemented with sucrose. Recombinant CaM53 was 
shown to activate the enzyme glutamate decarboxylase, a known plant CaM-dependent enzyme, and the authors used genetic complementation to demonstrate that an intact CaM53 gene was able to rescue a yeast mutant $(\operatorname{cmd} 1 \Delta)$ defective in this $\mathrm{CaM}$ gene variant. The later result confirmed that this nuclear-targeted CaM isoform (CaM53) is both functionally active, and biologically relevant. Nuclear localization of CaM has also been reported by Kushwaha et al. [98] who identified four CaM isoforms in Arabidopsis and demonstrated that one of these isoforms (CAM7) directly interacted with promoters of several lightinducible genes to promote photomorphogenesis. Overexpression of CAM7 resulted in hyperphotomorphogenic growth and increased expression of the light-inducible genes.

As efforts to understand the seemingly infinite versatility of $\mathrm{Ca}^{2+/} \mathrm{CaM}$ signaling in plant cell processes advance, it appears certain that $\mathrm{CaM}$ will continue to be revealed as a fundamental global regulator and facilitator of intracellular signaling cross-talk, organelle function, and gene regulatory cascades in plant cells.

\section{Summary Comments}

As work to unravel and understand the exquisitely complicated signaling networks that control plant processes forges ahead, an increasingly prominent regulatory role for $\mathrm{CaM}$ and CMLs will emerge. The evolutionary conservation and persistence of CaM, and related CMLs, as key $\mathrm{Ca}^{2+}$ sensors support their role as regulatory allies that modulate the expression and activity of other $\mathrm{Ca}^{2+} / \mathrm{CaM}$ dependent effector proteins, such as those noted. The complexity and functional ubiquity of the $\mathrm{Ca}^{2+}$ signal in regulating diverse plant growth, development, and defense responses presents major challenges and opportunities for investigators in coming years to elucidate specific biological functions for each of these highly conserved $\mathrm{CaM}$ gene family members. Transduction of the $\mathrm{Ca}^{2+}$ signal by $\mathrm{CaM}$ (or any CBP) can be viewed as a two-step process involving initial activation of $\mathrm{CaM}$ by $\mathrm{Ca}^{2+}$ ion binding, followed by direct interaction with, and consequent modulation of, a target protein. In this scenario, challenging questions whose answers have remained stubbornly elusive to date include (i) How do seemingly minor differences in amino acid sequences among highly conserved $\mathrm{CaM}$ isoforms dictate differential downstream responses to given $\mathrm{Ca}^{2+}$ signatures(?) and (ii) How do different CaM isoforms (or other EF-hand proteins) interact with, and differentially modulate, their respective target proteins(?).

Acknowledgments Generous funding by Wyoming INBRE for Braxton Tyree to support his undergraduate research training is greatly appreciated. S.A. Dhekney holds the E.A. Whitney Endowed Professorship in the UW Department of Plant Sciences.

\section{References}

1. Abdalsamee MK, Giampà M, Niehaus K, Müller C (2014) Rapid incorporation of glucosinolates as a strategy used by a herbivore to prevent activation by myrosinases. Insect Biochem Mol Biol 52:115-123

2. Abdel-Hamid H, Chin K, Moeder W, Yoshioka K (2011) High throughput chemical screening supports the involvement of $\mathrm{Ca}^{2+}$ in cyclic nucleotide-gated ion channel-mediated programmed cell death in Arabidopsis. Plant Signal Behav 6: $1817-1819$

3. Abel S, Savchenko T, Levy M (2005) Genome-wide comparative analysis of the IQD gene families in Arabidopsis thaliana and Oryza sativa. BMC Evo Biol 5:72. doi:10.1186/1471-2148$5-72$

4. Abel S, Bürstenbinder K, Müller J (2013) The emerging function of IQD proteins as scaffolds in cellular signaling and trafficking. Plant Signal Behav 8(6):e24369. doi:10.4161/psb.24369

5. Arazi T, Sunkar R, Kaplan B, Fromm H (1999) A tobacco plasma membrane calmodulin-binding transporter confers $\mathrm{Ni}^{2+}$ tolerance and $\mathrm{Pb}^{2+}$ hypersensitivity in transgenic plants. Plant $\mathrm{J}$ 20:171-182

6. Asai S, Ichikawa T, Nomura H, Kobayashi M, Kamiyoshihara Y, Mori H, Kadota Y, Zipfel C, Jones JD, Yoshioka H (2013) The variable domain of a plant calcium-dependent protein kinase (CDPK) confers subcellular localization and substrate recognition for NADPH oxidase. Biol Chem 288:14332-14340

7. Asano T, Hayashi N, Kikuchi S, Ohsugi R (2012) CDPKmediated abiotic stress signaling. Plant Signal Behav 7:817-821

8. Astier J, Lindermayr C (2012) Nitric oxide-dependent posttranslational modification in plants: an update. Int $\mathrm{J}$ Mol Sci 13:15193-15208

9. Bae H, Kim MS, Sicher RC, Bae HJ, Bailey BA (2006) Necrosis- and ethylene-inducing peptide from Fusarium oxysporum induces a complex cascade of transcripts associated with signal transduction and cell death in Arabidopsis. Plant Physiol 141(3):1056-1067

10. Bakshi M, Oelmüller R (2014) WRKY transcription factors: Jack of many trades in plants. Plant Signal Behav 9:e27700. Epub 2014 Feb 3

11. Banerjee J, Magnani R, Nair M, Dirk LM, DeBolt S, Maiti IB, Houtz RL (2013) Calmodulin-mediated signal transduction pathways in Arabidopsis are fine-tuned by methylation. Plant Cell 25(11):4493-4511

12. Batistic O, Kudla J (2012) Analysis of calcium signaling pathways in plants. Biochim Biophys Acta (BBA) 1820:1283-1293

13. Batistic O, Waadt R, Steinhorst L, Held K, Kudla J (2010) CBLmediated targeting of CIPKs facilitates the decoding of calcium signals emanating from distinct cellular stores. Plant $\mathrm{J}$ 61: 211-222

14. Baudouin E (2013) Hancock JT (2014) Nitric oxide signaling in plants. Front Plant Sci 4:553. doi:10.3389/fpls.2013.00553

15. Beck M, Heard W, Mbengue M, Robatzek S (2012) The INs and OUTs of pattern recognition receptors at the cell surface. Curr Opin Plant Biol 15:367-374

16. Bednarek P (2012) Sulfur-containing secondary metabolites from Arabidopsis thaliana and other Brassicaceae with function in plant immunity. ChemBioChem 13(13):1846-1859

17. Bellin D, Asai S, Delledonne M, Yoshioka H (2013) Nitric oxide as a mediator for defense responses. Mol Plant Microbe Interact 26:271-277 
18. Bender KW, Dobney S, Ogunrinde A, Chiasson D, Mullen RT, Teresinski HJ, Singh P, Munro K, Smith SP, Snedden WA (2014) The calmodulin-like protein CML43 functions as a salicylic-acid-inducible root-specific $\mathrm{Ca}(2+)$ sensor in Arabidopsis. Biochem J 457:127-136

19. Benn G, Wang CQ, Hicks DR, Stein J, Guthrie C, Dehesh K (2014) A key general stress response motif is regulated nonuniformly by CAMTA transcription factors. Plant J. doi:10. $1111 /$ tpj. 12620

20. Bergey DR, Howe GA, Ryan CA (1996) Polypeptide signaling for plant defensive genes exhibits analogies to defense signaling in animals. Proc Natl Acad Sci USA 93(22):12053-12058

21. Berkey R, Bendigeri D, Xiao S (2012) Sphingolipids and plant defense/disease: the "death" connection and beyond. Front Plant Sci 3:68. doi:10.3389/fpls.2012.00068

22. Bjornson M, Benn G, Song X, Comai L, Franz AK, Dandekar AM, Drakakaki G, Dehesh K (2014) Distinct roles for MAPK signaling and CAMTA3 in regulating the peak time and amplitude of the plant general stress response. Plant Physiol 166(2):988-996

23. Bonza MC, De Michelis MI (2011) The plant $\mathrm{Ca}^{2+}$-ATPase repertoire: biochemical features and physiological functions. Plant Biol (Stuttg) 13:421-430

24. Boonburapong B, Buaboocha T (2007) Genome-wide identification and analyses of the rice calmodulin and related potential calcium sensor proteins. BMC Plant Biol 7:4. doi:10.1186/14712148-5-72

25. Bouche N, Scharlat A, Snedden W, Bouchez D, Fromm H (2002) A novel family of calmodulin-binding transcription activators in multicellular organisms. J Biol Chem 277:2185121861

26. Boudsocq M, Sheen J (2013) CDPKs in immune and stress signaling. Trends Plant Sci 18:30-40

27. Boudsocq M, Willmann MR, McCormack M, Lee H, Shan L, He P, Bush J, Cheng SH, Sheen J (2010) Differential innate immune signalling via $\left.\mathrm{Ca}^{2+}\right)$ sensor protein kinases. Nature 464:418-422

28. Boursiac Y, Lee SM, Romanowsky S, Blank R, Sladek C, Chung WS, Harper JF (2010) Disruption of the vacuolar calcium-ATPases in Arabidopsis results in the activation of a salicylic acid-dependent programmed cell death pathway. Plant Physiol 154:1158-1171

29. Burstenbinder K, Savchenko T, Müller J, Adamson AW, Stamm G, Kwong R, Zipp BJ, Dinesh DC, Abel S (2012) Arabidopsis calmodulin-binding protein IQ67-domain 1 localizes to microtubules and interacts with kinesin light chain-related protein-1. J Biol Chem 288:1871-1882

30. Bush DS, Jones RL (1990) Measuring intracellular $\mathrm{Ca}^{2+}$ levels in plant cells using the fluorescent probes, indo- 1 and fura-21 progress and prospects. Plant Physiol 93:841-845

31. Bussemer J, Chigri F, Vothknecht UC (2009) Arabidopsis ATPase family gene 1-like protein 1 is a calmodulin-binding AAA+-ATPase with a dual localization in chloroplasts and mitochondria. FEBS J 276:3870-3880

32. Capoen W, Sun J, Wysham D, Otegui MS, Venkateshwaran M, Hirsch S, Miwa H, Downie JA, Morris RJ, Ane JM, Oldroyd GE (2011) Nuclear membranes control symbiotic calcium signaling of legumes. Proc Natl Acad Sci USA 108:14348-14353

33. Chazin WJ (2011) Relating form and function of EF-hand calcium binding proteins. Acc Chem Res 44:171-179

34. Chen L, Song Y, Li S, Zhang L, Zou C, Yu D (2012) The role of WRKY transcription factors in plant abiotic stresses. Biochim Biophys Acta 1819:1200-1288

35. Chen CW, Panzeri D, Yeh YH, Kadota Y, Huang PY, Tao CN, Roux M, Chien SC, Chin TC, Chu PW, Zipfel C, Zimmerli L (2014) The Arabidopsis malectin-like leucine-rich repeat receptor-like kinase IOS1 associates with the pattern recognition receptors FLS2 and EFR and is critical for priming of patterntriggered immunity. Plant Cell 26(7):3201-3219

36. Cheval C, Aldon D, Galaud JP, Ranty B (2013) Calcium/calmodulin-mediated regulation of plant immunity. Biochim Biophys Acta 1833:1766-1771

37. Chi Y, Yang Y, Zhou Y, Zhou J, Fan B, Yu JQ, Chen Z (2013) Protein-protein interactions in the regulation of WRKY transcription factors. Mol Plant 6:287-300

38. Chigri F, Hormann F, Stamp A, Stammers DK, Bolter B, Soll J, Vothknecht UC (2006) Calcium regulation of chloroplast protein translocation is mediated by calmodulin binding to Tic 32 . Proc Natl Acad Sci USA 103:16051-16056

39. Chigri F, Flosdorff S, Pilz S, Kölle E, Dolze E, Gietl C, Vothknecht U (2012) The Arabidopsis calmodulin-like proteins AtCML30 and AtCML3 are targeted to mitochondria and peroxisomes, respectively. Plant Mol Biol 78:211-222

40. Chin K, DeFalco TA, Moeder W, Yoshioka K (2013) The Arabidopsis cyclic nucleotide-gated ion channels AtCNGC2 and AtCNGC4 work in the same signaling pathway to regulate pathogen defense and floral transition. Plant Physiol 163:611624

41. Choi HW, Lee DH, Hwang BK (2009) The pepper calmodulin gene $\mathrm{CaCaM} 1$ is involved in reactive oxygen species and nitric oxide generation required for cell death and the defense response. Mol Plant Microbe Interact 22:1389-1400

42. Chun HJ, Park HC, Koo SC, Lee JH, Park CY, Choi MS, Kang CH, Baek D, Cheong YH, Yun DJ, Chung WS, Cho MJ, Kim MC (2012) Constitutive expression of mammalian nitric oxide synthase in tobacco plants triggers disease resistance to pathogens. Cells 34:463-471

43. Clarkson DT, Brownlee C, Ayling SM (1988) Cytoplasmic calcium measurements in intact higher plants cells: results from fluorescence ratio imaging of Fura-2. Cell Sci 91:71-80

44. Coll NS, Epple P, Dangl JL (2011) Programmed cell death in the plant immune system. Cell Death Differ 18:1247-1256

45. Corpas FJ, Barroso JB, Palma JM, del Río LA (2013) Peroxisomes as cell generators of reactive nitrogen species (RNS) signal molecules. Subcell Biochem 69:283-298

46. Danquah A, de Zelicourt A, Colcombet J, Hirt H (2014) The role of $\mathrm{ABA}$ and MAPK signaling pathways in plant abiotic stress responses. Biotechnol Adv 32:40-52

47. Day IS, Reddy VS, Shad Ali G, Reddy AS (2002) Analysis of EF-hand-containing proteins in Arabidopsis. Genome Biol 3(10):research0056.1-research0056.24

48. Delaunois B, Jeandet P, Clément C, Baillieul F, Dorey S, Cordelier S (2014) Uncovering plant-pathogen crosstalk through apoplastic proteomic studies. Front Plant Sci 3(5):249. doi:10. 3389/fpls.2014.00249

49. Dell'Aglio E, Giustini C, Salvi D, Brugière S, Delpierre F, Moyet L, Baudet M, Seigneurin-Berny D, Matringe M, Ferro M, Rolland N, Curien G (2013) Complementary biochemical approaches applied to the identification of plastidial calmodulinbinding proteins. Mol BioSyst 9:1234-1248

50. Delledonne M, Zeier J, Marocco A, Lamb C (2001) Signal interactions between nitric oxide and reactive oxygen intermediates in the plant hypersensitive disease resistance response. Proc Natl Acad Sci USA 98(23):13454-13459

51. Denancé N, Sánchez-Vallet A, Goffner D, Molina A (2013) Disease resistance or growth: the role of plant hormones in balancing immune responses and fitness costs. Front Plant Sci 24:155

52. Derksen H, Rampitsch C, Daayf F (2013) Signaling cross-talk in plant disease resistance. Plant Sci 207:79-87

53. Ding SW, Lu R (2012) Virus-derived siRNAs and piRNAs in immunity and pathogenesis. Opin Virol 1:533-544 
54. Ding SW, Voinnet O (2007) Antiviral immunity directed by small RNAs. Cell 130:413-426

55. Doares SH, Narvaez-Vasquez J, Conconi A, Ryan CA (1995) Salicylic acid inhibits synthesis of proteinase inhibitors in tomato leaves induced by systemin and jasmonic acid. Plant Physiol 108(4):1741-1746

56. Dodd AN, Kudla J, Sanders D (2010) The language of calcium signaling. Ann Rev Plant Biol 61:593-620

57. Du L, Ali GS, Simons KA, Hou J, Yang T, Reddy AS, Poovaiah BW (2009) $\mathrm{Ca}\left({ }^{2+}\right) /$ calmodulin regulates salicylic-acid-mediated plant immunity. Nature 457:1154-1158

58. Dubiella U, Seybold H, Durian G, Komander E, Lassig R, Witte CP, Schulze WX, Romeis T (2013) Calcium-dependent protein kinase/NADPH oxidase activation circuit is required for rapid defense signal propagation. Proc Natl Acad Sci USA 110:87448749

59. Finka A, Goloubinoff P (2013) The CNGCb and CNGCd genes from Physcomitrella patens moss encode for thermosensory calcium channels responding to fluidity changes in the plasma membrane. Cell Stress Chaperones 19(1):83-90

60. Finkler A, Ashery-Padan R, Fromm H (2007) CAMTAs: calmodulin-binding transcription activators from plants to human. FEBS Lett 581(21):3893-3898

61. Fischer C, Kugler A, Hoth S, Dietrich P (2013) An IQ domain mediates the interaction with calmodulin in a plant cyclic nucleotide-gated channel. Plant Cell Physiol 54:573-584

62. Fraiture M, Brunner F (2014) Killing two birds with one stone: trans-kingdom suppression of PAMP/MAMP-induced immunity by T3E from enteropathogenic bacteria. Front Microbiol 5:320. doi:10.3389/fmicb.2014.00320

63. Frederickson MDE, Loake GJ (2014) Redox regulation in plant immune function. Antioxid Redox Signal 21(9):1373-1388

64. Frei dit Frey N, Mbengue M, Kwaaitaal M, Nitsch L, Altenbach D, Häweker H, Lozano-Duran R, Njo MF, Beeckman T, Huettel B, Borst JW, Panstruga R, Robatzek S (2012) Plasma membrane calcium ATPases are important components of receptor-mediated signaling in plant immune responses and development. Plant Physiol 159:798-809

65. Frei dit Frey N, Garcia AV, Bigeard J, Zaag R, Bueso E, Garmier M, Pateyron S, de Tauzia-Moreau ML, Brunaud V, Balzergue S, Colcombet J, Aubourg S, Martin-Magniette ML, Hirt H (2014) Functional analysis of Arabidopsis immune-related MAPKs uncovers a role for MPK3 as negative regulator of inducible defences. Genome Biol 15(6):R87

66. Fu ZQ, Dong X (2013) Systemic acquired resistance: turning local infection into global defense. Annu Rev Plant Biol 64: 839-863

67. Fu ZQ, Yan S, Saleh A, Wang W, Ruble J, Oka N, Mohan R, Spoel SH, Tada Y, Zheng N, Dong X (2012) NPR3 and NPR4 are receptors for the immune signal salicylic acid in plants. Nature 486:228-232

68. Galon Y, Nave R, Boyce JM, Nachmias D, Knight MR, Fromm H (2008) Calmodulin-binding transcription activator (CAMTA) 3 mediates biotic defense responses in Arabidopsis. FEBS Lett 582:943-948

69. Gao X, He P (2013) Nuclear dynamics of Arabidopsis calciumdependent protein kinases in effector-triggered immunity. Plant Signal Behav 8(4):e23868

70. Gaupels F, Kuruthukulangarakoola GT, Durner J (2011) Upstream and downstream signals of nitric oxide in pathogen defence. Curr Opin Plant Biol 14:707-714

71. Gelli A, Higgins VJ, Blumwald E (1997) Activation of plant plasma membrane $\mathrm{Ca}^{2+}$ permeable channels by race-specific fungal elicitors. Plant Physiol 113:269-279

72. Giacometti S, Marrano CA, Bonza MC, Luoni L, Limonta M, De Michelis MI (2012) Phosphorylation of serine residues in the
$\mathrm{N}$-terminus modulates the activity of ACA8, a plasma membrane $\mathrm{Ca}^{2+}$-ATPase of Arabidopsis thaliana. J Exp Bot 63:1215-1224

73. Gimenez-Ibanez S, Solano R (2013) Nuclear jasmonate and salicylate signaling and crosstalk in defense against pathogens. Front Plant Sci 4:72

74. González A, Cabrera Mde L, Henríquez MJ, Contreras RA, Morales B, Moenne A (2013) Cross-talk among calcium, hydrogen peroxide, and nitric oxide and activation of gene expression involving calmodulins and calcium-dependent protein kinases in Ulva compressa exposed to copper excess. Plant Physiol 158:1451-1462

75. González-Besteiro MA, Ulm R (2013) ATR and MKP1 play distinct roles in response to UV-B stress in Arabidopsis. Plant J 73(6): 1034-1043

76. Groß F, Durner J, Gaupels F (2013) Nitric oxide, antioxidants and prooxidants in plant defence responses. Front Plant Sci 4:419. doi:10.3389/fpls.2013.00419

77. Guan Q, Wu J, Yue X, Zhang Y, Zhu J (2013) A nuclear calcium-sensing pathway is critical for gene regulation and salt stress tolerance in Arabidopsis. PLoS Genet 9(8):e1003755

78. Nie H, Zhao C, Wu G, Wu Y, Chen Y, Tang D (2012) SR1, a calmodulin-binding transcription factor, modulates plant defense and ethylene-induced senescence by directly regulating NDR1 and EIN3. Plant Physiol 158:1847-1859

79. Harding SA, Oh SH, Roberts DM (1997) Transgenic tobacco expressing a foreign calmodulin gene shows an enhanced production of active oxygen species. EMBO J 16:1137-1144

80. Hashimoto K, Kudla J (2011) Calcium decoding mechanisms in plants. Biochimie 93:2054-2059

81. Henikoff S (2007) ENCODE and our very busy genome. Nat Genet 39:817-818

82. Heo WD, Lee SH, Kim MC, Kim JC, Chung WS, Chun HJ, Lee KJ, Park CY, Park HC, Choi JY, Cho MJ (1999) Involvement of specific calmodulin isoforms in salicylic acid-independent activation of plant disease resistance responses. Proc Natl Acad Sci USA 96:766-771

83. Ishida H, Rainaldi M, Vogel HJ (2009) Structural studies of soybean calmodulin isoform 4 bound to the calmodulin-binding domain of tobacco mitogen-activated protein kinase phosphatase-1 provide insights into a sequential target binding mode. Biol Chem 284:28292-28305

84. Ishida M, Hara M, Fukino N, Kakizaki T, Morimitsu Y (2014) Glucosinolate metabolism, functionality and breeding for the improvement of Brassicaceae vegetables. Breed Sci 64(1): 48-59

85. Jarrett HW, Brown CJ, Black CC, Cormier MJ (1982) Evidence that calmodulin is in the chloroplast of peas and serves a regulatory role in photosynthesis. J Biol Chem 257:13795-13804

86. Jeandroz S, Lamotte O, Astier J, Rasul S, Trapet P, Besson-Bard A, Bourque S, Nicolas-Francès V, Ma W, Berkowitz G, Wendehenne D (2013) There's more to the picture than meets the eye: Nitric oxide cross-talk with $\mathrm{Ca}^{2+}$ signaling. Plant Physiol 163(2):459-470

87. Jia L, Chu H, Wu D, Feng M, Zhao L (2014) Role of calmodulin in thermotolerance. Plant Signal Behav 9:e28887

88. Kaplan B, Sherman T, Fromm H (2007) Cyclic nucleotide-gated channels in plants. FEBS Lett 581:2237-2246

89. Kim DS, Hwang BK (2012) The pepper MLO gene, $\mathrm{CaMLO}_{2}$, is involved in the susceptibility cell-death response and bacterial and oomycete proliferation. Plant J 72:843-855

90. Kim MC, Chung WS, Yun DJ, Cho MJ (2009) Calcium and calmodulin-mediated regulation of gene expression in plants. Mol Plant 2:13-21

91. Kim Y, Park S, Gilmour SJ, Thomashow MF (2013) Roles of CAMTA transcription factors and salicylic acid in configuring 
the low temperature transcriptome and freezing tolerance of Arabidopsis. Plant J 75:364-376

92. Kissoudis C, van de Wiel C, Richard GF, Visser RGF, van der Linden G (2014) Enhancing crop resilience to combined abiotic and biotic stress through the dissection of physiological and molecular crosstalk. Front Plant Sci 5:207. doi:10.3389/fpls. 2014.00207

93. Knight $\mathrm{H}$ (2000) Calcium signaling during abiotic stress in plants. Int Rev Cytol 195:269-324

94. Knight M, Campbell AK, Smith SM, Trewavas AJ (1991) Transgenic plant aequorin reports the effects of touch and coldshock and elicitors on cytoplasmic calcium. Nature 352:524526

95. Kong X, Lv W, Jiang S, Zhang D, Cai G, Pan J, Li D (2013) Genome-wide identification and expression analysis of calciumdependent protein kinase in maize. BMC Genomics 14:433-442

96. Kudla J, Batistic O, Hashimoto K (2010) Calcium signals: the lead currency of plant information processing. Plant Cell 22:541-563

97. Kuhn S, Bussemer J, Chigri F, Vothknecht UC (2009) Calcium depletion and calmodulin inhibition affect the import of nuclear encoded proteins into plant mitochondria. Plant J 58:694-705

98. Kushwaha R, Singh A, Chattopadhyay S (2008) Calmodulin7 plays an important role as transcriptional regulator in Arabidopsis seedling development. Plant Cell 20:1747-1759

99. Lachaud C, Prigent E, Thuleau P, Grat S, Da Silva D, Brière C, Mazars C, Cotelle V (2013) 14-3-3-regulated $\mathrm{Ca}^{2+}$ )-dependent protein kinase CPK3 is required for sphingolipid-induced cell death in Arabidopsis. Cell Death Differ 20:209-217

100. Laluk K, Prasad KV, Savchenko T, Celesnik H, Dehesh K, Levy M, Mitchell-Olds T, Reddy AS (2012) The calmodulin-binding transcription factor SIGNAL RESPONSIVE1 is a novel regulator of glucosinolate metabolism and herbivory tolerance in Arabidopsis. Plant Cell Physiol 53:2008-2015

101. Lam E, Zhang Y (2012) Regulating the reapers: activating metacaspases for programmed cell death. Trends Plant Sci $17: 487-494$

102. Leba LJ, Perochon A, Cheval C, Ranty B, Galaud JP, Aldon D (2012) CML9, a multifunctional Arabidopsis thaliana calmodulin-like protein involved in stress responses and plant growth. Plant Signal Behav 7:1121-1124

103. Lecourieux D, Ranjeva R, Pugin A (2006) Calcium in plant defense-signaling pathways. New Phytol 171:249-269

104. Lee K, Song EH, Kim HS, Yoo JH, Han HJ, Jung MS, Lee SM, Kim KE, Kim MC, Cho MJ, Chung WS (2008) Regulation of MAPK phosphatase 1 (AtMKP1) by calmodulin in Arabidopsis. Biol. Chem 283:23581-23588

105. Levine A, Pennell RI, Alvarez ME, Palmer R, Lamb C (1996) Calcium-mediated apoptosis in a plant hypersensitive disease resistance response. Curr Biol 6:427-437

106. Levy M, Wang Q, Kaspi R, Parrella MP, Abel S (2005) Arabidopsis IQD1, a novel calmodulin-binding nuclear protein, stimulates glucosinolate accumulation and plant defense. Plant $\mathbf{J}$ 43:79-96

107. Li Z, Yue H, Xing D (2012) MAP Kinase 6-mediated activation of vacuolar processing enzyme modulates heat shock-induced programmed cell death in Arabidopsis. New Phytol 195:85-96

108. Liese A, Romeis T (2013) Biochemical regulation of in vivo function of plant calcium-dependent protein kinases (CDPK). Biochim Biophys Acta 1833:1582-1589

109. Lippmann D, Lehmann C, Florian S, Barknowitz G, Haack M, Mewis I, Wiesner M, Schreiner M, Glatt H, Brigelius-Flohé R, Kipp AP (2014) Glucosinolates from pak choi and broccoli induce enzymes and inhibit inflammation and colon cancer differently. Food Funct 5:1073-1081
110. Lopreiato R, Giacomello M, Carafoli E (2014) The plasma membrane calcium pump: new ways to look at an old enzyme. J Biol Chem 289(15):10261-10268

111. Luan S (2009) The CBL-CIPK network in plant calcium signaling. Trends Plant Sci 14:37-42

112. Ma W (2011) Roles of $\mathrm{Ca}^{2+}$ and cyclic nucleotide gated channel in plant innate immunity. Plant Sci 181:342-346

113. Ma W, Berkowitz GA (2011) $\mathrm{Ca}^{2+}$ conduction by plant cyclic nucleotide gated channels and associated signaling components in pathogen defense signal transduction cascades. New Phytol 190:566-572

114. Ma W, Smigel A, Tsai YC, Braam J, Berkowitz GA (2008) Innate immunity signaling: cytosolic $\mathrm{Ca}^{2+}$ elevation is linked to downstream nitric oxide generation through the action of calmodulin or a calmodulin-like protein. Plant Physiol 148:818-828

115. Ma W, Smigel A, Verma R, Berkowitz GA (2009) Cyclic nucleotide gated channels and related signaling components in plant innate immunity. Plant Signal Behav 4:277-282

116. Ma Y, Walker RK, Zhao Y, Berkowitz GA (2012) Linking ligand perception by PEPR pattern recognition receptors to cytosolic $\mathrm{Ca}^{2+}$ elevation and downstream immune signaling in plants. Proc Natl Acad Sci USA 109:19852-19857

117. Manzoor H, Chiltz A, Madani S, Vatsa P, Schoefs B, Pugin A, Garcia-Brugger A (2012) Calcium signatures and signaling in cytosol and organelles of tobacco cells induced by plant defense elicitors. Cell Calcium 51:434-444

118. Markham JE, Lynch DV, Napier JA, Dunn TM, Cahoon EB (2013) Plant sphingolipids: function follows form. Curr Opin Plant Biol 16(3):350-357

119. Mazars C, Brière C, Bourque S, Thuleau P (2011) Nuclear calcium signaling: an emerging topic in plants. Biochimie 93:2068-2074

120. McAinsh MR, Pittman JK (2009) Shaping the calcium signature. New Phytol 181:275-294

121. McCormack E, Tsai YC, Braam J (2005) Handling calcium signaling: Arabidopsis CaMs and CMLs. Trends Plant Sci 10:383-389

122. Meng X, Zhang S (2013) MAPK cascades in plant disease resistance signaling. Annu Rev Phytopathol 51:245-266

123. Moeder W, Urquhart W, Ung H, Yoshioka K (2011) The role of cyclic nucleotide-gated ion channels in plant immunity. Mol Plant 4:442-452

124. Monaghan J, Zipfel C (2012) Plant pattern recognition receptor complexes at the plasma membrane. Curr Opin Plant Biol $15: 349-357$

125. Mortimer JC, Yu X, Albrecht S, Sicilia F, Huichalaf M, Ampuero D, Michaelson LV, Murphy AM, Matsunaga T, Kurz S, Stephens E, Baldwin TC, Ishii T, Napier JA, Weber AP, Handford MG, Dupree P (2013) Abnormal glycosphingolipid mannosylation triggers salicylic acid-mediated responses in Arabidopsis. Plant Cell 25:1881-1894

126. Mur LA, Prats E, Pierre S, Hall MA, Hebelstrup KH (2013) Integrating nitric oxide into salicylic acid and jasmonic acid/ ethylene plant defense pathways. Front Plant Sci 4:215

127. Muthamilarasan M, Prasad M (2013) Plant innate immunity: an updated insight into defense mechanism. J Biosci. 38:433-449

128. Nagano Y, Inaba T, Furuhashi H, Sasaki Y (2001) Trihelix DNAbinding protein with specificities for two distinct cis-elements: both important for light down-regulated and dark-inducible gene expression in higher plants. J Biol Chem 276:22238-22243

129. Nakahara KS, Masuta C, Yamada S, Shimura H, Kashihara Y, Wada TS, Meguro A, Goto K, Tadamura K, Sueda K, Sekiguchi T, Shao J, Itchoda N, Matsumura T, Igarashi M, Ito K, Carthew RW, Uyeda I (2012) Tobacco calmodulin-like protein provides secondary defense by binding to and directing degradation of 
virus RNA silencing suppressors. Proc Natl Acad Sci USA 109(25):10113-10118. doi:10.1073/pnas.1201628109

130. Newman MA, Sundelin T, Nielsen JT, Erbs G (2013) MAMP (microbe-associated molecular pattern) triggered immunity in plants. Front Plant Sci 4:139. doi:10.3389/fpls.2013.00139

131. Oka K, Amano Y, Katou S, Seo S, Kawazu K, Mochizuki A, Kuchitsu K, Mitsuhara I (2013) Tobacco MAP kinase phosphatase (NtMKP1) negatively regulates wound response and induced resistance against necrotrophic pathogens and lepidopteran herbivores. Mol Plant Microbe Interact 26(6):668-675

132. Okazaki Y, Saito K (2014) Roles of lipids as signaling molecules and mitigators during stress response in plants. Plant $\mathbf{J}$ 79(4):584-596

133. Pardo JM, Reddy MP, Yang S, Maggio A, Huh GH, Matsumoto T, Coca MA, Paino-D'Urzo M, Koiwa H, Yun DJ, Watad AA, Bressan RA, Hasegawa PM (1998) Stress signaling through Ca21/ calmodulin-dependent protein phosphatase calcineurin mediates salt adaptation in plants. Proc Natl Acad Sci USA 95:9681-9686

134. Park CY, Lee JH, Yoo JH, Moon BC, Choi MS, Kang YH, Lee SM, Kim HS, Kang KY, Chung WS, Lim CO, Cho MJ (2005) WRKY group IId transcription factors interact with calmodulin. FEBS Lett 579:1545-1550

135. Pata MO, Hannun YA, Ng CK-Y (2010) Plant sphingolipids: decoding the enigma of the Sphinx. New Phytol 185:611-630

136. Pathak RK, Taj G, Pandey D, Arora S, Kumar A (2013) Modeling of the MAPK machinery activation in response to various abiotic and biotic stresses in plants by a system biology approach. Bio information 9:443-449

137. Perochon A, Aldon D, Galaud JP, Ranty B (2011) Calmodulin and calmodulin-like proteins in plant calcium signaling. Biochimie 93:2048-2053

138. Pitzschke A, Schikora A, Hirt H (2009) MAPK cascade signaling networks in plant defence. Curr Opin Plant Biol 12:421-426

139. Plattner H, Verkhratsky A (2013) $\mathrm{Ca}^{2+}$ signaling early in evolution: all but primitive. Cell Sci 126:2141-2150

140. Poovaiah BW, Du L, Wang H, Yang T (2013) Recent advances in calcium/calmodulin-mediated signaling with an emphasis on plant-microbe interactions. Plant Physiol 163:531-542

141. Qi Z, Verma R, Gehring C, Yamaguchi Y, Zhao Y, Ryan CA, Berkowitz GA (2010) $\mathrm{Ca}^{2+}$ signaling by plant Arabidopsis thaliana Pep peptides depends on AtPepR1, a receptor with guanylyl cyclase activity, and cGMP-activated $\mathrm{Ca}^{2+}$ channels. Proc Natl Acad Sci USA 107:21193-21198

142. Qiu Y, Xi J, Du L, Suttle JC, Poovaiah BW (2012) Coupling calcium/calmodulin-mediated signaling and herbivore-induced plant response through calmodulin-binding transcription factor AtSR1/CAMTA3. Plant Mol Biol 79:89-99

143. Raffaele S, Leger A, Roby D (2009) Very long chain fatty acid and lipid signaling in the response of plants to pathogens. Plant Signal Behav 4(2):94-99

144. Rainaldi M, Yamniuk AP, Murase T, Vogel HJ (2007) Calciumdependent and -independent binding of soybean calmodulin isoforms to the calmodulin binding domain of tobacco MAPK phosphatase-1. Biol Chem 282:6031-6042

145. Ranf S, Eschen-Lippold L, Pecher P, Lee J, Scheel D (2011) Interplay between calcium signalling and early signalling elements during defence responses to microbe- or damage-associated molecular patterns. Plant J 68:100-113

146. Ranty B, Cotelle V, Galaud JP, Mazars C (2012) Nuclear calcium signaling and its involvement in transcriptional regulation in plants. Adv Exp Med Biol 740:1123-1143

147. Rasmussen MW, Roux M, Petersen M, Mundy J (2012) MAP kinase cascades in Arabidopsis innate immunity. Front Plant Sci 3:169

148. Reddy AS, Reddy VS, Golovkin M (2000) A calmodulin binding protein from Arabidopsis is induced by ethylene and contains a DNA-binding motif. Biochem Biophys Res Commun 279(3):762-769

149. Reddy AS, Ali GS, Celesnik H, Day IS (2011) Coping with stresses: roles of calcium- and calcium/calmodulin-regulated gene expression. Plant Cell 23:2010-2032

150. Rodríquez-Concepcíon M, Yalovsky S, Zik M, Fromm H, Gruissem W (1999) The prenylation status of a novel plant calmodulin directs plasma membrane or nuclear localization of the protein. EMBO J 18:1996-2007

151. Romeis T, Herde M (2014) From local to global: CDPKs in systemic defense signaling upon microbial and herbivore attack. Curr Opin Plant Biol 20:1-10

152. Rushton PJ, Somssich IE, Ringler P, Shen QJ (2010) WRKY transcription factors. Trends Plant Sci 15:247-258

153. Rushton DL, Tripathi P, Rabara RC, Lin J, Ringler P, Boken AK, Langum TJ, Smidt L, Boomsma DD, Emme NJ, Chen X, Finer JJ, Shen QJ, Rushton PJ (2012) WRKY transcription factors: key components in abscisic acid signalling. Plant Biotechnol J 10(1):2-11

154. Samajová O, Komis G, Samaj J (2013) Emerging topics in the cell biology of mitogen-activated protein kinases. Trends Plant Sci 18:140-148

155. Sanchez-Barrena MJ, Martinez-Ripoll M, Albert A (2013) Structural biology of a major signaling network that regulates plant abiotic stress: The CBL-CIPK mediated pathway. Int J Mol Sci 14:5734-5749

156. Saucedo-García M, González-Solís A, Rodríguez-Mejía P, Olivera-Flores Tde J, Vázquez-Santana S, Cahoon EB, GavilanesRuiz M (2011) Reactive oxygen species as transducers of sphinganine-mediated cell death pathway. Plant Signal Behav 6:1616-1619

157. Scheler C, Durner J, Astier J (2013) Nitric oxide and reactive oxygen species in plant biotic interactions. Curr Opin Plant Biol 16(4):534-539

158. Schwessinger B, Ronald PC (2012) Plant innate immunity: perception of conserved microbial signatures. Annu Rev Plant Biol 63:451-482

159. Segonzac C, Feike D, Gimenez-Ibanez S, Hann DR, Zipfel C, Rathjen JP (2011) Hierarchy and roles of pathogen-associated molecular pattern-induced responses in Nicotiana benthamiana. Plant Physiol 156:687-699

160. Sinha AK, Jaggi M, Raghuram B, Tuteja N (2011) Mitogenactivated protein kinase signaling in plants under abiotic stress. Plant Signal Behav 6:196-203

161. Smékalová V, Doskočilová A, Komis G, Samaj J (2014) Crosstalk between secondary messengers, hormones and MAPK modules during abiotic stress signalling in plants. Biotechnol Adv 32:2-11

162. Stael S, Rocha A, Robinson AJ, Kmiecik P, Vothknecht UC, Teige M (2011) Arabidopsis calcium-binding mitochondrial carrier proteins as potential facilitators of mitochondrial ATPimport and plastid SAM-import. FEBS Lett 585:3935-3940

163. Stael S, Wurzinger B, Mair A, Mehlmer N, Vothknecht UC, Teige M (2012) Plant organellar calcium signaling: an emerging field. J Exp Bot 63:1525-1542

164. Tadamura K, Nakahara KS, Masuta C, Uyeda I (2012) Woundinduced rgs-CaM gets ready for counter response to an early stage of viral infection. Plant Signal Behav 7:1548-1551

165. Taj G, Agarwal P, Grant M, Kumar A (2010) MAPK machinery in plants: recognition and response to different stresses through multiple signal transduction pathways. Plant Signal Behav 11:1370-1378

166. Takahashi F, Mizoguchi T, Yoshida R, Ichimura K, Shinozaki K (2011) Calmodulin-dependent activation of MAP kinase for ROS homeostasis in Arabidopsis. Mol Cell 41:649-660

167. Tavernier E, Wendehenne D, Blein JP, Pugin A (1995) Involvement of free calcium in action of cryptogein, a 
proteinaceous elicitor of hypersensitive reaction in tobacco cells. Plant Physiol 109:1025-1031

168. Tena G, Boudsocq M, Sheen J (2011) Protein kinase signaling networks in plant innate immunity. Curr Opin Plant Biol 14:519-529

169. Thomma BP, Nurnberger T, Joosten MH (2011) Of PAMPs and effectors: the blurred PTI-ETI dichotomy. Plant Cell 23:4-15

170. Thuleau P, Aldon D, Cotelle V, Brière C, Ranty B, Galaud JP, Mazars C (2013) Relationships between calcium and sphingolipid-dependent signalling pathways during the early steps of plant-pathogen interactions. Biochim Biophys Acta 1833:1590-1594

171. Trewavas AJ, Malho R (1998) $\mathrm{Ca}^{2+}$ signaling in plant cells: the big network! Curr Opin Plant Biol 1:428-433

172. Tripathi P, Rabara RC, Rushton PJ (2014) A systems biology perspective on the role of WRKY transcription factors in drought responses in plants. Planta 239:255-266

173. Truman W, Sreekanta S, Lu Y, Bethke G, Tsuda K, Katagiri F, Glazebrook J (2013) The CALMODULIN-BINDING PROTEIN60 family includes both negative and positive regulators of plant immunity. Plant Physiol 163(4):1741-1751

174. Tsai YC, Delk NA, Chowdhury NI, Braam J (2007) Arabidopsis potential calcium sensors regulate nitric oxide levels and the transition to flowering. Plant Signal Behav 2:446-454

175. Tsai YC, Koo Y, Delk NA, Gehl B, Braam J (2013) Calmodulinrelated CML24 interacts with ATG4b and affects autophagy progression in Arabidopsis. Plant J 73:325-335

176. Tsuda K, Mine A, Bethke G, Igarashi D, Botanga CJ, Tsuda Y, Glazebrook J, Sato M, Katagiri F (2013) Dual regulation of gene expression mediated by extended MAPK activation and salicylic acid contributes to robust innate immunity in Arabidopsis thaliana. PLoS Genet 9(12):e1004015

177. Vadassery J, Reichelt M, Hause B, Gershenzon J, Boland W, Mithöfer A (2012) CML42-mediated calcium signaling coordinates responses to Spodoptera herbivory and abiotic stresses in Arabidopsis. Plant Physiol 159:1159-1175

178. Van der Does D, Leon-Reyes A, Koornneef A, Van Verk MC, Rodenburg N, Pauwels L, Goossens A, van Verk MC, Bol JF, Linthorst HJ (2011) WRKY transcription factors involved in activation of SA biosynthesis genes. BMC Plant Biol 11:89

179. Velayev NV, Bates DG, Heslop-Harrison P, Postlethwaite I, Kotov NV (2008) Elucidating the mechanisms of cooperative calcium-calmodulin interactions: a structural systems biology approach. BMC Syst Biol 2:48-53

180. Walker RK, Berkowitz GA (2013) Detection of reactive oxygen species downstream of cyclic nucleotide signals in plants. Methods Mol Biol 1016:245-252

181. Wang C, Deng P, Chen L, Wang X, Ma H, Hu W, Yao N, Feng Y, Chai R, Yang G, He G (2013) A wheat WRKY transcription factor TaWRKY10 confers tolerance to multiple abiotic stresses in transgenic tobacco. PLoS One 8:1-13

182. Wang Y, Loake GJ, Chu C (2013) Cross-talk of nitric oxide and reactive oxygen species in plant programed cell death. Front Plant Sci 4:314. doi:10.3389/fpls.2013.00314

183. Watanabe N, Lam E (2011) Calcium-dependent activation and autolysis of Arabidopsis metacaspase 2d. Biol Chem 286: 10027-10040

184. Weng H, Yoo CY, Gosney MJ, Hasegawa PM, Mickelbart MV (2012) Poplar GTL1 is a $\mathrm{Ca}^{2+} /$ calmodulin-binding transcription factor that functions in plant water use efficiency and drought tolerance. PLoS One 7(3):e32925

185. Wiermer M, Feys BJ, Parker JE (2005) Plant immunity: the EDS1 regulatory node. Curr Opin Plant Biol 8:383-389

186. Winde I, Wittstock U (2011) Insect herbivore counteradaptations to the plant glucosinolate-myrosinase system. Phytochemistry 72(13): 1566-1575

187. Wu L, Chen H, Curtis C, Fu ZQ (2014) Go in for the kill: how plants deploy effector-triggered immunity to combat pathogens. Virulence 5(7). [Epub ahead of print]

188. Wurzinger B, Mair A, Pfister B, Teige M (2012) Cross-talk of calcium-dependent protein kinase and MAP kinase signaling. Plant Signal Behav 6:8-12

189. Xi J, Qiu Y, Du L, Poovaiah BW (2012) Plant-specific trihelix transcription factor AtGT2L interacts with calcium/calmodulin and responds to cold and salt stresses. Plant Sci 185-186:274280

190. Xu GY, Rocha PS, Wang ML, Xu ML, Cui YC, Li LY, Zhu YX, Xia X (2011) A novel rice calmodulin-like gene, OsMSR2, enhances drought and salt tolerance and increases ABA sensitivity in Arabidopsis. Planta 234:47-59

191. Yamnuik AP, Vogel HJ (2004) Calmodulin's flexibility allows for promiscuity in its interactions with target proteins and peptides. Mol Biotechnol 27:33-57

192. Yang T, Poovaiah BW (2000) An early ethylene up-regulated gene encoding a calmodulin-binding protein involved in plant senescence and death. J Biol Chem 275(49):38467-38473

193. Yang T, Poovaiah BW (2002) A calmodulin-binding/CGCG box DNA-binding protein family involved in multiple signaling pathways in plants. J Biol Chem 277(47):45049-45058

194. Yang T, Peng H, Whitaker BD, Jurick WM (2013) Differential expression of calcium/calmodulin-regulated SISRs in response to abiotic and biotic stresses in tomato fruit. Physiol Plant 148:445-455

195. Yu M, Lamattina L, Spoel SH, Loake GJ (2014) Nitric oxide function in plant biology: a redox cue in deconvolution. New Phytol 202(4):1142-1156

196. Zegzouti H, Jones B, Frasse P, Marty C, Maitre B, Latch A, Pech JC, Bouzayen M (1999) Ethylene-regulated gene expression in tomato fruit: characterization of novel ethylene-responsive and ripening-related genes isolated by differential display. Plant J 18:589-600

197. Zelman AK, Dawe A, Gehring C, Berkowitz GA (2012) Evolutionary and structural perspectives of plant cyclic nucleotidegated cation channels. Front Plant Sci 3:95

198. Zhang L, Du L, Shen C, Yang Y, Poovaiah BW (2014) Regulation of plant immunity through ubiquitin-mediated modulation of $\mathrm{Ca}(2+)$-calmodulin-AtSR1/CAMTA3 signaling. Plant J 78(2): 269-281

199. Zhao Y, Liu W, Xu YP, Cao JY, Braam J, Cai XZ (2013) Genome-wide identification and functional analyses of calmodulin genes in Solanaceous species. BMC Plant Biol 13(1):70

200. Zimmermann S, Nurnberger T, Frachisse JM, Wirtz W, Guern J, Hedrich R, Scheel D (1997) Receptor-mediated activation of a plant $\mathrm{Ca}^{2+}$-permeable ion channel involved in pathogen defense. Proc Natl Acad Sci USA 94:2751-2755 